ISSN 2620-6760, Vol. 2, No. 2, Oktober 2019

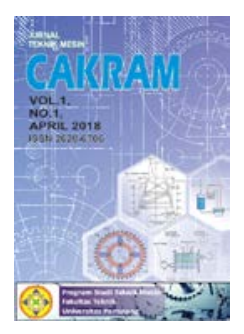

\title{
ANALISIS MATERIAL RUMAH KOPLING PADA MOTOR MATIC AKIBAT PANAS
}

\author{
Nur Rohmat ${ }^{1}$ \\ ${ }^{1}$ Program Studi Teknik Mesin, Universitas Pamulang, Jl. Surya Kencana No.1, Tangerang Selatan, Indonesia \\ E-mail: dosen00597@unpam.ac.id
}

Masuk : 14 Juli 2019

Direvisi : 8 September 2019

Disetujui : 18 Oktober 2019

\begin{abstract}
Abstrak:Untuk memindahkan daya mesin keroda belakang motor matic menggunakan teknologi transmisi otomatis (CVT). Gangguan yang umum terjadi pada transmisi otomatis antara lain: Pully penggeraknya aus, kopling bergetar dan saat idlle roda belakang masih bergerak. Kerusakan yang terjadi pada kopling diantaranya: sepatu kopling terkikis, drum tidak center dan abrasive. Analisa kemungkinan penyebab utama terjadinya kerusakan adalah gesekan antara drum dengan Sepatu kopling karena beban berlebih. Metode yang digunakan yaitu: Pengamatan secara visual dan perubahan sifat mekanis logam matrial drum melalui uji laboratorium diantaranya: Pengujian komposisi kimia, uji kekerasan dan uji metalografi. Kesimpulan dari penelitian ini mendapatkan hasil akhir bahwa kerusakan drum karena panas sehingga kwalitas drum menurun, hal ini terbukti dengan perubahan fisik dan kecenderungan penurunan kekerasan material pada drum. Dengan penambahan luas bidang pendingin drum tidak mengalami kecenderungan penurunan kekerasan material dan tidak mengalami perubahan bentuk.
\end{abstract}

Kata kunci: Sistem Transmisi Otomatis, Drum Kopling, Uji kekerasan dan Uji Metalografi.

Abstract: To move power the engine to the rear wheel motor automatic motorcycle with license number use technology automatic transmission (CVT). A generally occurs in automatic transmission are: Drive pully worn, clutch vibrating and when idle the rear wheel is still moving. The destruction in clutch are clutch shoe eroded, drum is not center and abrasive. Analyze the most likely cause of the damage is the friction between the drum with the clutch shoes because of exceed loads. The methodology that was use are visual observation and change of mechanical properties of metal clutch drum material through laboratory test among others: testing of chemical composition, hardness test and metallographic test. The conclusions of this study get the final result that the drum damage due to overheat, with the result that the quality of the drum is decreasing. With the addition of the cooling area of the drum does not experience a tendency to decrease material hardness and does not change a shape.

Keywords: automatic transmission system, drum clutch, violent test and metallographic test.

\section{PENDAHULUAN}

Motor matik merupakan sepeda motor yang menggunakan sistem transmisi otomatis (Continously Variable Transmission / CVT). Transmisi otomatis merupakan teknologi perpindahan tenaga dengan menggunakan dua pulley yang dihubungkan dengan sebuah belt. Diameter pulley dapat membesar dan mengecil secara otomatis sesuai dengan putaran mesin. Hal ini terjadi karena pada kedua pulley bekerja gaya sentrifugal yang dihasilkan oleh roller yang terdapat didalam pulley[1]. Drum kopling merupakan bagian yang menghubungkan tenaga dari putaran mesin melalui belt drive ke drive shaft.

Dari hasil pengamatan visual pada drum kopling menunjukkan bahwa kerusakan terjadi pada area gesekan antara drum kopling dengan Sepatu kopling. Guna memastikan komposisi material serta faktor - faktor lainnya perlu dilakukan pengkajian umur operasional dengan pengujian laboratorium dan simulasi penggunaan. Pengujian 
yang dilakukan adalah uji komposisi material, uji kekerasan, dan uji metalografi dan melakukan pengamatan struktur mikro.

\section{METODOLOGI}

Metodologi yang digunakan dalam penelitian ini melakukan pengumpulan data primer dan sekunder melalui inspeksi lapangan, pengambilan data visual, sampel material uji, pengujian, studi literatur, pengolahan data dan analisa sampai dengan mendapatkan penyebab terjadinya kerusakan. Secara garis besar proses penelitian yang dilakukan untuk mendapatkan penyebab kegagalan drum pada motor matic sebagai berikut:

a. Identifikasi masalah

b. Kegiatan pengumpulan informasi data

c. Pemeriksaan visual

d. Pengujian laboratorium

e. Analisa dan pembahasan

f. Kesimpulan dan saran

Pengujian laboratorium dilakukan di B2TKS-BPP Teknologi Puspiptek Serpong dan Laboraturium Departemen Teknik Metalurgi dan Material.

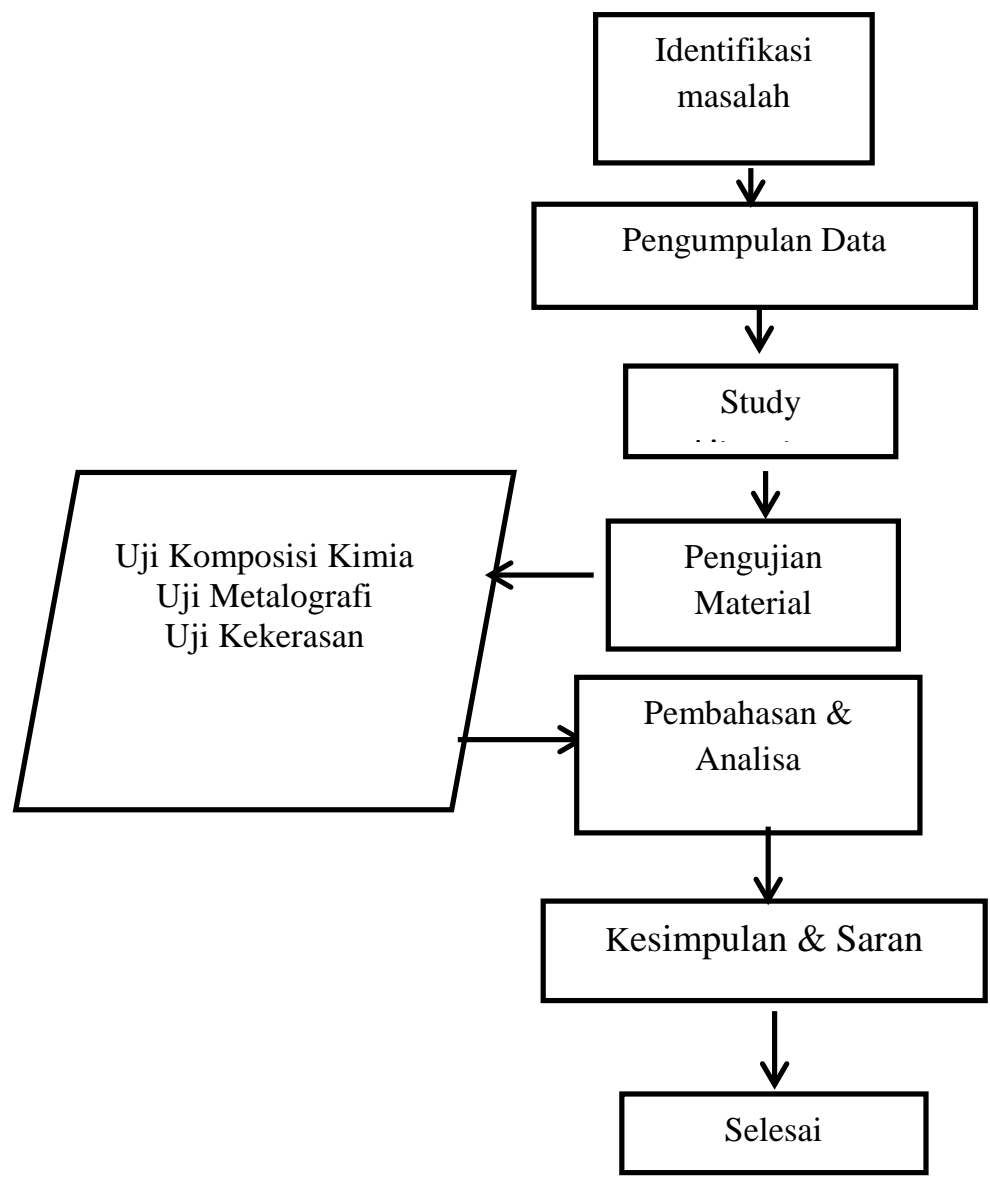

Gambar 1 Diagram alir penelitian

\section{HASIL DAN PEMBAHASAN}

Pada penelitian ini menganalisa penyebab terjadinya kerusakan drum pada motor matik. Analisa penyebab terjadinya kerusakan dan menganalisa kelayakan pakai pada drum kopling dalam oprasional motor matic dari data 
Jurnal Teknik Mesin: CAKRAM 2019

Nur Rohmat, Analisis Material Rumah Kopling Pada Motor Matik Akibat Panas

jumlah kerusakan, jumlah pemakaian drum kopling dan sistem pemeliharaan (maintenance practice) tersebut akan menghubungkan jenis kerusakan yang terjadi dengan langkah - langkah perawatan yang harus dilakukan.

\section{A. Inspeksi Visual.}

Pemeriksaan obyek secara langsung dilakukan untuk memastikan terjadinya kerusakan agar mendapatkan data data otentik untuk proses analisa kerusakan dan upaya perbaikan. Pemeriksaan obyek secara langsung dilakukan dengan mengukur dimensi drum. Diameter drum memiliki ukuran standar $112 \mathrm{~mm}$ dan batas serfisnya 12.5 mm. Pengukuran dimensi drum sampel A, B dan sampel C. Hasil pengukuran dimensi ditunjukkan pada Tabel 1.

Tabel 1 Tabel hasil pengukuran

\begin{tabular}{|c|c|c|c|c|}
\hline Sampel & A & B & C & Perbedaan \\
\hline Diameter dalam titik 1 & $112 \mathrm{~mm}$ & $112 \mathrm{~mm}$ & $112 \mathrm{~mm}$ & Sampel A, B \& C tidak ada perbedaan \\
\hline Diameter dalam titik 2 & $112,3 \mathrm{~mm}$ & $112 \mathrm{~mm}$ & $112,2 \mathrm{~mm}$ & Sampel A Lebih besar dari sampel B \& C \\
\hline Diameter Luar titik 1 & $120,5 \mathrm{~mm}$ & $120 \mathrm{~mm}$ & $120,3 \mathrm{~mm}$ & Sampel A Lebih besar dari sampel B \& C \\
\hline Diameter Luar titik 2 & $120 \mathrm{~mm}$ & $120 \mathrm{~mm}$ & $120 \mathrm{~mm}$ & Sampel A, B \& C tidak ada perbedaan \\
\hline
\end{tabular}

\section{B. Analisa Struktur Mikro Drum.}

Analisa struktur mikro dilakukan untuk mengetahui adanya unsur cacat material dan perubahanan struktur material. Hal ini dapat dilihat pada gambar 1

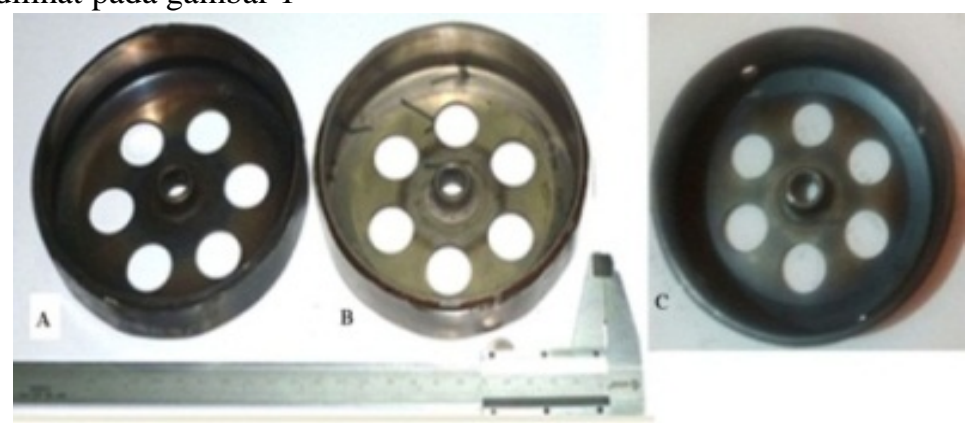

Gambar 1 Gambar drum Kopling. A. B dan C.

Drum kopling sampel A, B dan C mengalami beberapa proses yang dijelaskan sebagai berikut:

1. Kondisi dipakai 8 bulan tanpa penambahan lubang.

2. Kondisi baru dipakai 1 bulan.

3. Kondisi dipakai 8 bulan dan ditambahkan 4 lubang pada permukaan drum.

\section{Drum A telah dipakai 8 bulan tanpa penambahan lobang.}

Photo makro drum A, rusak memperlihatkan adanya perubahan warna pada seluruh permukaan drum baik dibagian luar maupun bagian dalam, hal ini terjadi karena adanya gesekan antara drum dengan sepatu kopling. Hal ini dapat dilihat pada gambar 2. Untuk melihat struktur mikro drum Sampel A dilakukan pengujian dengan 3 lokasi yang berbeda yaitu pengujian pada titik A1, A2 dan A3. Hal ini dapat dilihat pada gambar 3

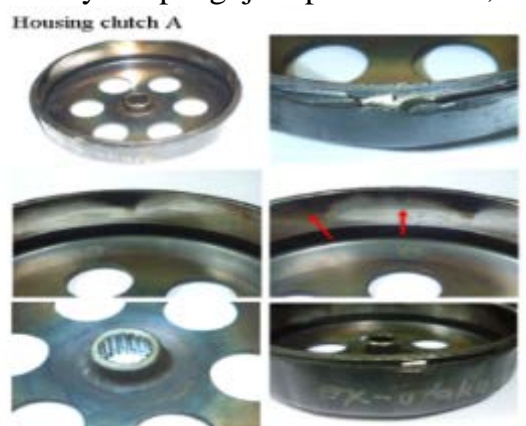

Gambar 2 Gambar Makro Drum kopling A rusak

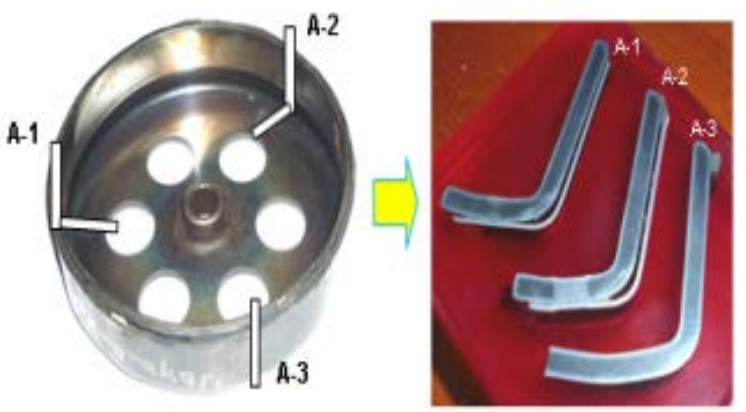

Gambar 3 Gambar Lokasi pengambilan sampel drum A 


\section{a. Potongan drum sampel A. lokasi A1}

Pada sampel drum sampel A, lokasi A1 dilakukan pengujian pada 2 sampel sebagai berikut:

1) Struktur mikro sampel A1 pelat dalam (lokasi, 2) pelat bagian dalam drum bagian sisi gesek dengan sepatu kopling struktur mikronya berupa matrik bainit-ferit halus sedangkan dibagian tengah berupa feritik dengan butir perlit menyebar merata. Etsa: nital 2\%. Hal ini dapat dilihat pada gambar 4

Sampel A1
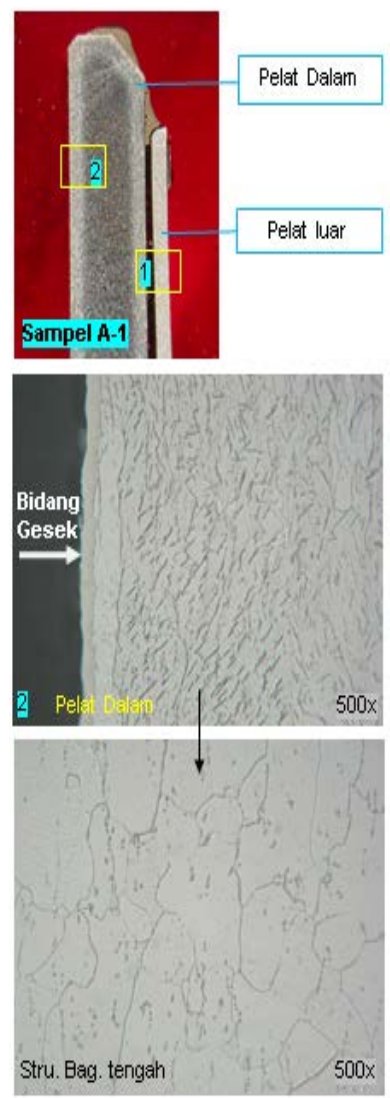

Gambar 4 Gambar Struktur mikro drum A1 (lokasi 1dan 2).
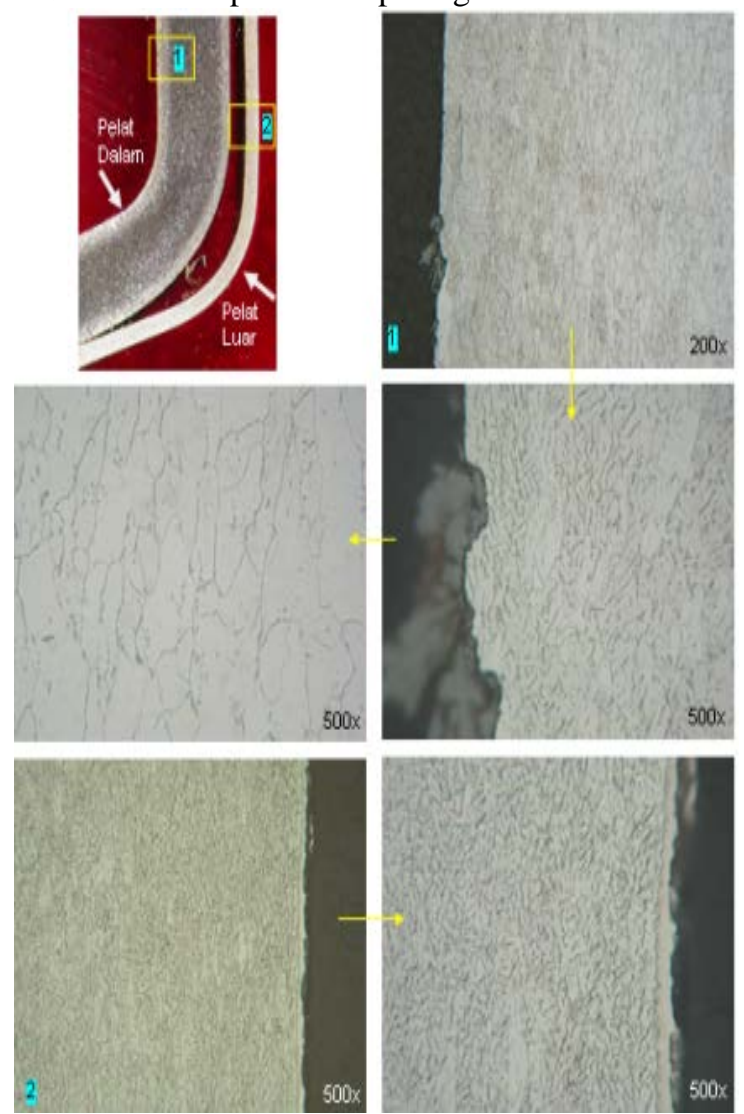

Gambar 5 Gambar Struktur mikro drum sampel A1 pelat bagian dalam dan pelat bagian luar

2) Struktur mikro sampel A1 pelat dalam (lokasi 1) struktur mikro berupa matrik bainit-ferit halus. Pelat bagian luar (lokasi 2) struktur mikro berupa matrik bainit-ferit. Etsa: nital 2\%. Hal ini dapat dilihat pada gambar 5

\section{b. Potongan drum sampel A, lokasi A2}

Struktur mikro sampel A2, pelat bagian luar dan dalam, struktur mikro berupa matrik bainit-ferit. Struktur mikro di bagian las titik berupa bainit-ferit dan tidak ditemukan adanya cacat maupun retak akibat pengelasan maupun pemakain. Etsa: nital 2\%. Hal ini dapat dilihat pada gambar 6 

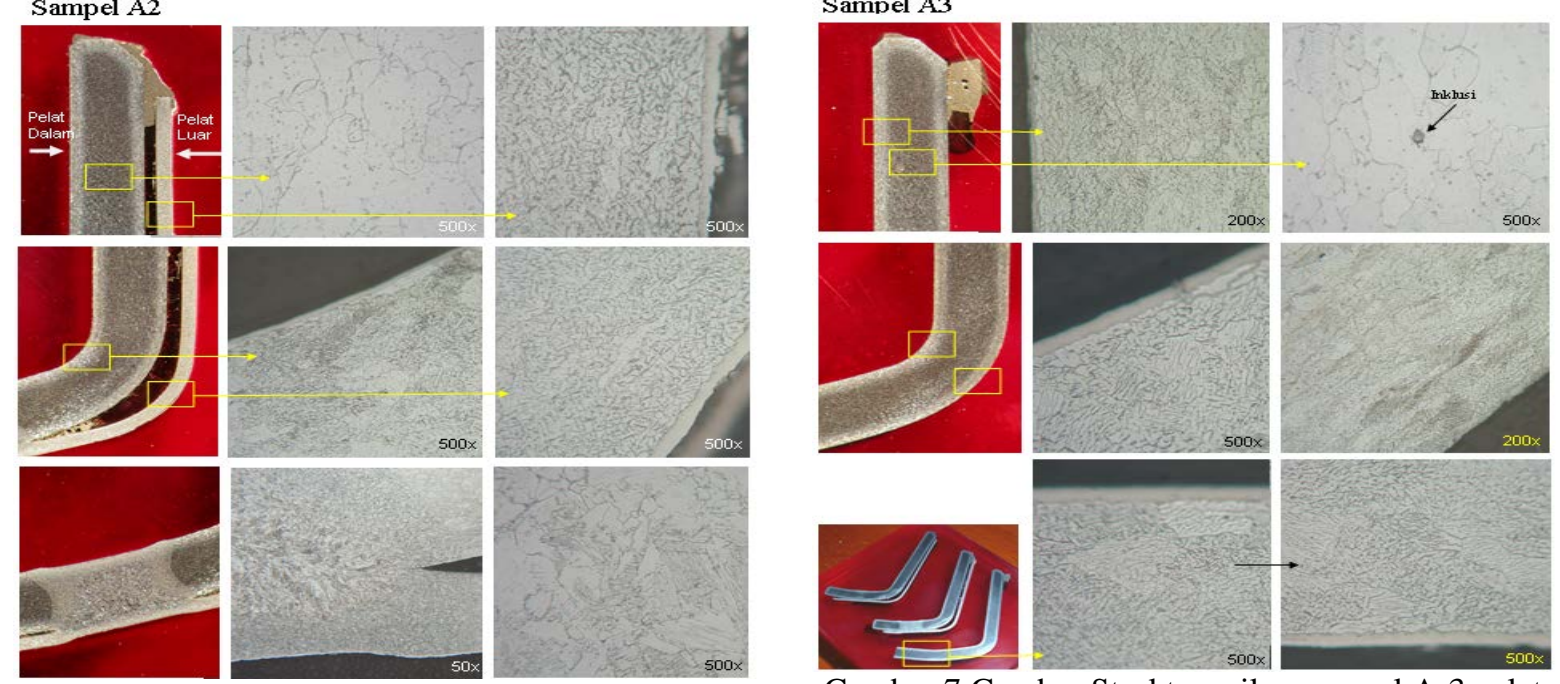

Gamabar 6 Gambar Struktur mikro sampel A-2 Pelat dalam.
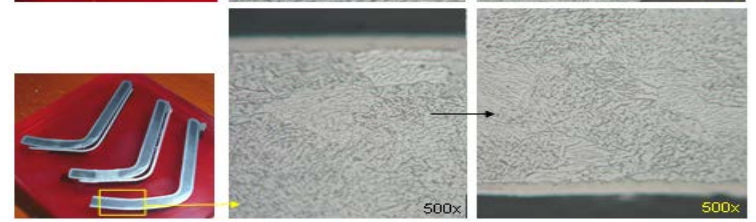

Gambar 7 Gambar Struktur mikro sampel A-3 pelat dalam.

\section{c. Potongan drum sampel A, lokasi A3}

Struktur mikro berupa matrik bainit-ferit halus dan dibagian tengah berupa feritik dengan butir perlit menyebar merata. Pada bagian gesek struktur mikro berupa matrik bainit-ferit dan dibagian yang tidak bergesekan struktur mikro berupa bainit-ferit. Etsa: nital 2\%. Hal ini dapat dilihat pada gambar 7

\section{Drum Sampel B, sampel dipakai 1 bulan}

a. Potongan drum sampel B Plat luar. Hal ini dapat dilihat pada gambar 8

b. Potongan drum sampel B Plat dalam. Hal ini dapat dilihat pada gambar 9

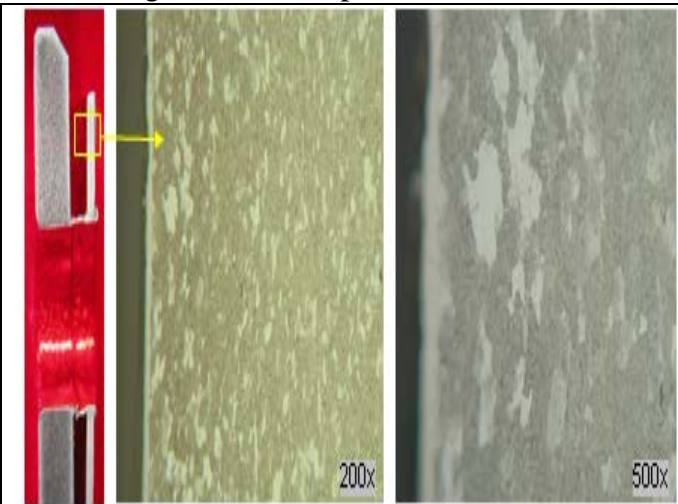

Gambar 8 Gambar Struktur mikro pelat luar (tebal $2 \mathrm{~mm}$ ) berupa feritperlit. Etsa: nital 2\%
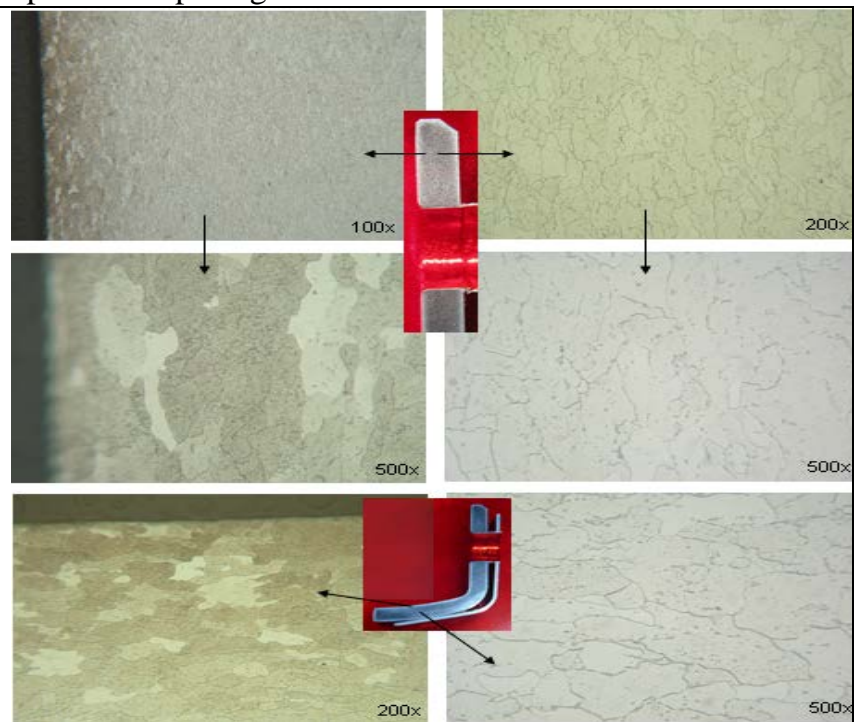

Gambar 9 Gambar Struktur mikro pelat dalam tebal $4 \mathrm{~mm}$ berupa ferit-perlit. Etsa: nital $2 \%$

\section{Drum Sampel C, dipakai 8 bulan dengan penambahan 4 lobang.}

Penambahan lobang dengan diameter $8 \mathrm{~mm}$ guna menambah luas bidang pendingin, pengambilan sampel didaerah yang berlubang dan tidak berlubang. Hal ini dapat dilihat pada gambar 10 

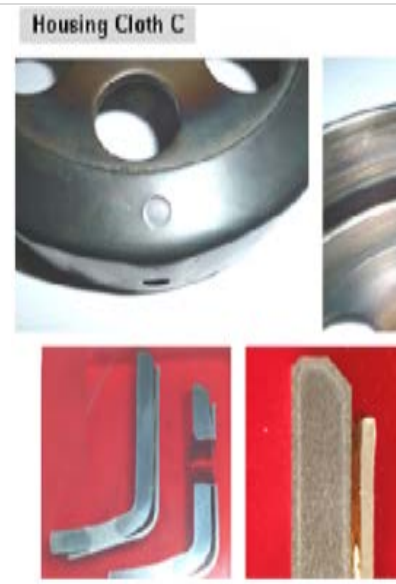

Gamabar 10 Gambar Drum sampel C dengan lobang pada bidang gesek drum dengan sepatu kopling.

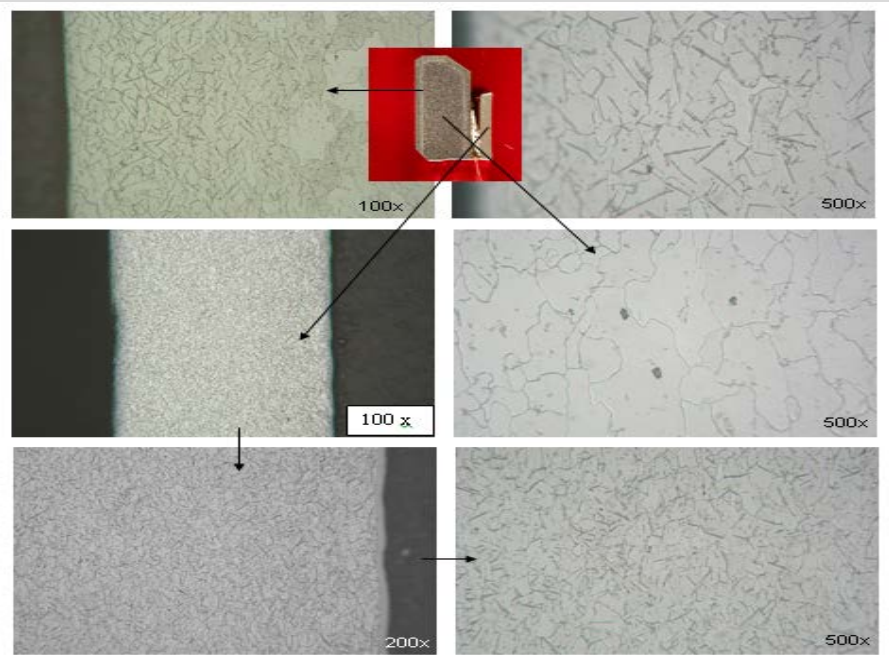

Gambar 11 Gambar Sampel C Dari 2 sampel yang diambil di daerah yang berlainan tidak ditemukan adanya perubahan struktur.

a. Potongan drum kopling sampel C.

Struktur mikro sampel C dari 2 sampel yang diambil di daerah yang berlainan tidak ditemukan adanya perubahan dan perbedaan struktur. Dapat dilihat pada gambar 11

b. Potongan drum sampel C, pelat dalam tebal $4 \mathrm{~mm}$ pada bagian tepi berupa bainit-feritik dan pelat luar berupa feritik bentuk bainit. Etsa: nital 2\%. Dapat dilihat pada gambar 12
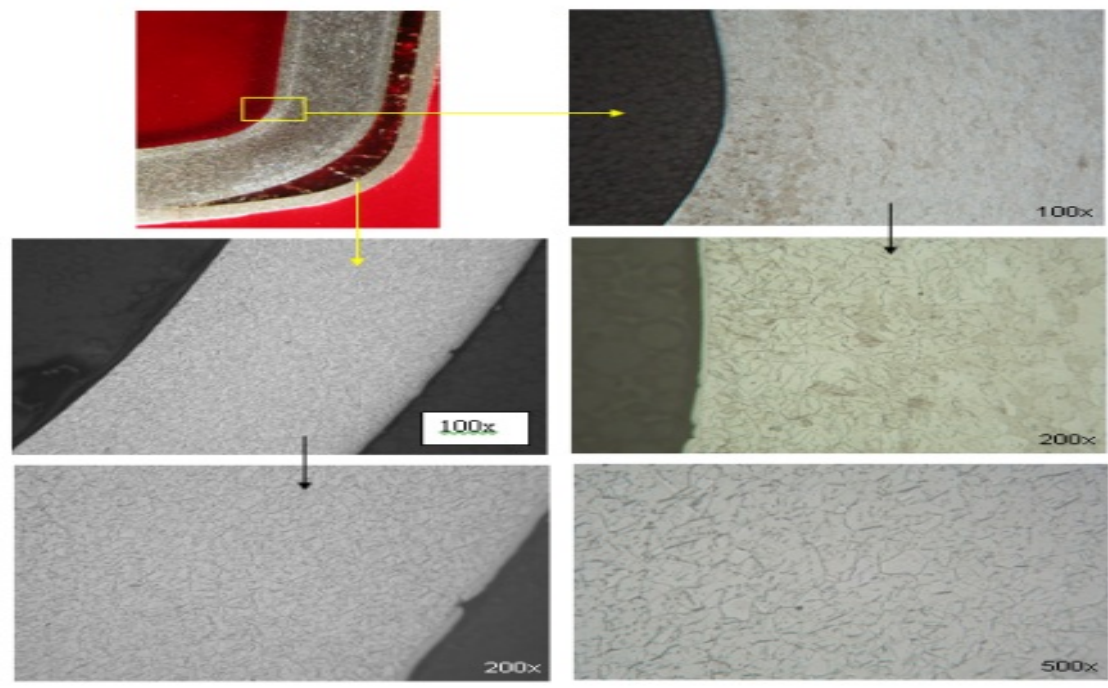

\section{Analisa Komposisi Kimia}

Gambar 12 Gambar Struktur mikro pelat dalam dengan tebal 4 mm. kimia.

Berdasarkan hasil pemeriksaan visual maka dipandang perlu untuk melakukan pengujian analisa komposisi

Tabel 2 Hasil uji komposisi kimia Drum Kopling

\begin{tabular}{|c|c|c|c|}
\hline \multicolumn{2}{|c|}{$\begin{array}{l}\text { Drum Kopling bagian dalam } \\
\text { Material : steel } \\
\text { Standar Uji: ASTM A751 }\end{array}$} & \multicolumn{2}{|c|}{$\begin{array}{l}\text { Drum Kopling bagian luar } \\
\text { Material : steel } \\
\text { Standar Uji : ASTM A751 }\end{array}$} \\
\hline \multirow{2}{*}{ Unsur } & Result (wt \%) & \multirow{2}{*}{ Unsur } & Result (wt \%) \\
\hline & Drum Kopling & & Drum Kopling \\
\hline
\end{tabular}




\begin{tabular}{|c|c|c|c|}
\hline $\mathrm{Fe}$ & 99,6 & $\mathrm{Fe}$ & 99,4 \\
\hline $\mathrm{C}$ & 0,0372 & $\mathrm{C}$ & 0,0367 \\
\hline $\mathrm{Si}$ & 0,0050 & $\mathrm{Si}$ & 0,0050 \\
\hline $\mathrm{Mn}$ & 0,229 & $\mathrm{Mn}$ & 0,239 \\
\hline $\mathrm{Cr}$ & 0,00179 & $\mathrm{Cr}$ & 0,00402 \\
\hline $\mathrm{Ni}$ & 0,0050 & $\mathrm{Ni}$ & 0,0144 \\
\hline $\mathrm{Mo}$ & 0,0040 & $\mathrm{Mo}$ & 0,0061 \\
\hline $\mathrm{Cu}$ & 0,0076 & $\mathrm{Cu}$ & 0,0460 \\
\hline $\mathrm{Al}$ & 0,0170 & $\mathrm{Al}$ & 0,0523 \\
\hline $\mathrm{V}$ & 0,0055 & $\mathrm{~V}$ & 0,0077 \\
\hline $\mathrm{Ti}$ & 0,0010 & $\mathrm{Ti}$ & 0,0010 \\
\hline $\mathrm{S}$ & 0,0107 & $\mathrm{~S}$ & 0,0221 \\
\hline $\mathrm{P}$ & 0,0201 & $\mathrm{P}$ & 0,0270 \\
\hline $\mathrm{Co}$ & 0,0020 & $\mathrm{Co}$ & 0,0020 \\
\hline $\mathrm{Nb}$ & 0,0030 & $\mathrm{Nb}$ & 0,0090 \\
\hline $\mathrm{W}$ & 0,0250 & $\mathrm{~W}$ & 0,0290 \\
\hline $\mathrm{Pb}$ & 0,0177 & $\mathrm{~Pb}$ & 0,0155 \\
\hline
\end{tabular}

Dari analisa komposisi kimia drum kopling kondisi baru, dipakai 8 bulan mengalami kerusakan dan dipakai 8 bulan ditambah lubang dapat disimpulkan bahwa:

1. Unsur karbon (C) pada drum baru (0.037 \% C) sesuai JIS G 4104 (0, 033 - 0, 38 \% C), pada kondisi rusak (0, $033 \% \mathrm{C})$ dan kondisi ditambah lobang (0, 035 \%C). Memperlihatkan perbedaan komposisi karbon sehingga drum terpengaruh efek panas dengan berkurangnya sifat kekerasan.

2. Unsur silikon (Si) pada drum baru (0, 050 \% Si) sesuai JIS G 4104 (0, 15 - 0, 35\% Si), kondisi rusak (0, 057 \% Si), kondisi diberi lubang (0, 050 \% Si) lebih tinggi dibandingkan standart sehingga ketahanan material kurang dan turunnya sifat mekanis logam. Unsur sulfur (S) pada drum baru (0. 0050 \% S) sesuai JIS G 4104 $(0,030 \% \mathrm{~S})$ namun pada kondisi rusak (0. $002 \% \mathrm{~S})$ dan ditambah lubang (0.003 \% S) lebih rendah dari standart, dengan rendahnya unsur sulfur (S) akan mempengaruhi sifat mampu mesin dan sifat kekerasannya.

3. Unsur mangan ( Mn ) pada drum baru (0. $229 \%$ Mn) sesuai JIS G 4104 (0. 60 - 0.85 \% Mn), pada kondisi rusak (0.160 \% Mn) dan kondisi ditambah lubang ( 0, $280 \% \mathrm{Mn}$ ) lebih tinggi sehingga material tahan pada temperatur tinggi.

4. Unsur phosfor (P) pada drum baru (0.020\% P) sesuai dengan JIS G 4104 (0. 030 \% P), kondisi rusak (0. $010 \% \mathrm{P})$ kondisi diberi lubang (0. $018 \% \mathrm{Mn})$ lebih rendah sehingga mempengaruhi terbentuknya fasa ferit dan meningkatkan ketahanan korosi dan oksidasi.

5. Unsur Besi (Fe) pada drum baru (99. 6 \% Fe) sesuai JIS G 4104 (93. 2\% Fe), pada kondisi rusak (91. 0\% Fe) dan kondisi drum ditambah lubang (95, 6\% Fe) merupakan material utama sehingga akan terpengaruh komposisinya jika unsur - unsur lainnya (Ni, Cr, Mo, V, Cu,W, Ti, Sn, Al, Pb, Nb, Zr, Zn) berubah.

\section{Analisa Kekerasan}

Analisa kekerasan pada drum dimaksudkan untuk menganalisa perubahan kekerasan akibat panas yang diterima. Uji kekerasan tersebut menggunakan metode hardnes Vickers. Hal ini dapat dilihat pada gambar 13

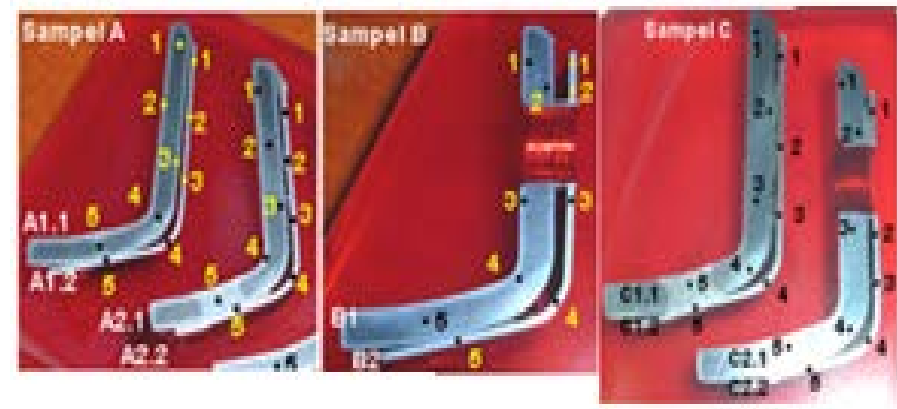

Gambar 13 Gambar Lokasi uji matrial Drum kopling 
Tabel 3 Hasil uji kekerasan drum kopling

Data alat uji kekerasan Vickers

Nama alat : Frank Finotest

Metode Uji : Hardnes Vickers (HV)

Beban (P) : $5 \mathrm{Kgf}$

Sudut Identor $\quad: 136^{\circ}$

Waktu Uji : 15 detik

\begin{tabular}{|c|c|c|c|c|c|c|c|c|c|c|}
\hline \multirow{4}{*}{$\mathrm{NO}$} & \multicolumn{10}{|c|}{ NILAI KEKERASAN, HV } \\
\hline & \multicolumn{4}{|c|}{$\begin{array}{c}\text { SAMPEL A } \\
\text { Dipakai } 8 \text { bulan tanpa penambahan } \\
\text { lubang pendingin }\end{array}$} & \multirow{2}{*}{\multicolumn{2}{|c|}{$\begin{array}{c}\text { SAMPEL B } \\
\text { dipakai } 1 \text { bulan }\end{array}$}} & \multicolumn{4}{|c|}{$\begin{array}{c}\text { SAMPEL C } \\
\text { Dipakai } 8 \text { bulan dengan penambahan } \\
\text { lubang pendingin }\end{array}$} \\
\hline & \multicolumn{2}{|c|}{ Sampel A1 } & \multicolumn{2}{|c|}{ Sampel A2 } & & & \multicolumn{2}{|c|}{ Sampel C1 } & \multicolumn{2}{|c|}{ Sampel C2 } \\
\hline & $\begin{array}{c}\text { A1.1 } \\
\text { Plat } \\
\text { Dalam }\end{array}$ & $\begin{array}{l}\text { A1.2 } \\
\text { Plat } \\
\text { Luar }\end{array}$ & $\begin{array}{c}\text { A2.1 } \\
\text { Plat } \\
\text { Dalam }\end{array}$ & $\begin{array}{l}\text { A2.2 } \\
\text { Plat } \\
\text { Luar }\end{array}$ & $\begin{array}{c}\text { B1.1 } \\
\text { Plat } \\
\text { Dalam }\end{array}$ & $\begin{array}{l}\text { B2.2 } \\
\text { Plat } \\
\text { Luar }\end{array}$ & $\begin{array}{c}\text { C1.1 } \\
\text { Plat } \\
\text { Dalam }\end{array}$ & $\begin{array}{l}\text { C1.2 } \\
\text { Plat } \\
\text { Luar }\end{array}$ & $\begin{array}{c}\text { C2.1 } \\
\text { Plat } \\
\text { Dalam }\end{array}$ & $\begin{array}{l}\text { C2.2 } \\
\text { Plat Luar }\end{array}$ \\
\hline 1 & 83 & 185 & 120 & 188 & 173 & 227 & 90 & 210 & 120 & 198 \\
\hline 2 & 152 & 180 & 83 & 187 & 150 & 227 & 152 & 192 & 152 & 192 \\
\hline 3 & 150 & 177 & 152 & 180 & 126 & 206 & 150 & 190 & 152 & 188 \\
\hline 4 & 113 & 120 & 113 & 123 & 137 & 192 & 126 & 135 & 132 & 134 \\
\hline 5 & 90 & 158 & 161 & 141 & 130 & 174 & 98 & 158 & 90 & 161 \\
\hline$\sum H A$ & 588 & 820 & 629 & 819 & 716 & 1026 & 616 & 885 & 646 & 873 \\
\hline & 117,6 & 164 & 125,8 & 163,8 & 143,2 & 205,2 & 123,2 & 177 & 129,2 & 174,6 \\
\hline
\end{tabular}

Dari tabel diatas nilai kekerasan pada permukaan drum dapat diartikan kode A (Pemakaian 8 bulan tanpa lobang, kode B (pemakain 1 bulan) dan kode C (Pemakaian 8 bulan dengan menambahkan lobang.

1. Sampel : A pada sampel A1. Sampel B. pada sampel B1. Sampel C pada sampel C1 (bagian drum yang bergesekan dengan sepatu kopling) dengan data sebagai berikut:

a. Keadaan baru digunakan 1 bulan kekerasan rata - rata sebesar 143, 2 HV

b. Penggunaan 8 bulan tanpa lobang 117, 6 HV.

c. Penggunaan 8 bulan dengan lobang kekerasan menjadi 123, 2 HV

2. $\quad$ Sampel : A1 pada sampel 2. Sampel B pada sampel B2. Sampel C1 pada sampel 2 (bagian luar drum tidak bergesekan dengan sepatu kopling) dengan data sebagai berikut:

a.Digunakan 1 bulan kekerasan rata - rata sebesar 205, 2 HV.

b.Penggunaan 8 bulan tanpa lobang $164 \mathrm{HV}$.

c.Penggunaan 8 bulan dengan lobang kekerasan menjadi $177 \mathrm{HV}$

3. Sampel : A pada sampel A2 sampel 1 \& C pada sampel C2 sampel 1 (bagian Dalam drum) dengan data sebagai berikut :

a.Penggunaan 8 bulan tanpa lobang 125, $8 \mathrm{HV}$

b.Penggunaan 8 bulan dengan lobang 129, $6 \mathrm{HV}$

4. Sampel: A pada sampel A2 sampel 2. \& C2 pada sampel 2 (bagian luar drum) dengan data sebagai berikut : a.Penggunaan 8 bulan tanpa lobang 163, $8 \underline{\mathrm{HV}}$

b.Penggunaan 8 bulan dengan lobang 174, $6 \mathrm{HV}$

\section{KESIMPULAN}

Berdasarkan hasil analisa yang diperoleh maka dapat diambil beberapa kesimpulan sebagai berikut:

a. Perubahan Struktur mikro pada sampel A yang tidak ditambahkan lobang, pada bagian tepi berupa matrik bainit-ferit halus, sedangkan dibagian tengah berupa feritik dengan butir perlit. Sampel C ditambahkan lubang, struktur mikro pada bagian tepi berupa bainit-feritik, sedangkan dibagian tengah berupa ferit-perlit. 
b. Inspeksi visual dan pengukuran dimensi pada drum yang ditambahkan lobang ukuran tidak mengalami perubahan, sedangkan drum kopling yang tidak ditambahkan lobang banyak mengalami perubahan. Hal ini dapat dibuktikan dengan hasil pengukuran pada sampel A, B \& C.

c. Kekerasan material drum yang tidak ditambahkan lobang terlihat mengalami penurunan nilai kekerasan dibandingkan dengan drum yang diberi lubang. Hal ini dapat dibuktikan dengan hasil uji kekerasan pada sampel A, B \& C.

d. Pengukuran suhu pada putaran 4360 Rpm tanpa beban selama 30 menit, drum tanpa lubang memiliki suhu $53,1^{\circ} \mathrm{C}$ dan drum dengan lubang memiliki suhu $48,1^{\circ} \mathrm{C}$ sehingga memiliki perbedaan $5^{\circ} \mathrm{C}$.

Kesimpulan dari penelitian drum yang ditambahkan lubang mengalami perubahan bila dibandingkan dengan drum yang tidak diberi lubang, baik kekerasan material, ukuran dimensi, struktur mikro dan suhu yang memiliki perbedaan $5^{0} \mathrm{C}$.

\section{DAFTAR PUSTAKA}

1. Yamaha Motor Engineering Training Center, System CVT, Edc-new model-nouvo II-03-ris.

2. Astra Honda Training Centre, System transmisi otomatis V matic, modul dasar.

3. Sularso \& Kiyokatsu Suga(2002) Dasar Perencanaan dan pemilihan. Elemen mesin. PT Pradnyana Paramita. Jakarta.

4. Kenji chijiiwa, Tata surdia, Teknik pengecoran logam, Balai pustaka, Bandung, November 1986

5. Lawrence H. Van Vlack. NY. Sriati Djaprie, Ilmu dan Teknologi Bahan. Edisi keempat 